\title{
Folkerettslig immunitet i norsk sivilprosess
}

Sondre Torp Helmersen

Førsteamanuensis, Det juridiske fakultet, UiT Norges arktiske universitet sondre.t.helmersen@uit.no

\section{Sammendrag:}

Folkeretten har regler om statsimmunitet og diplomatisk immunitet, som gir stater og deres representanter vern mot fremmede staters domstoler og andre myndigheter. Norsk sivilprosess har bestemmelser som sektormonisme, som sier at folkeretten går foran norsk lov ved motstrid. Dette utgangspunktet kan virke enkelt. Folkerettens immunitetsregler har vært oppe for norske domstoler i en rekke saker, og denne artikkelen viser at domstolene i flere saker har truffet motstridende eller uriktige konklusjoner. Flere spørsmål forblir uavklarte, både på det internasjonale og det nasjonale planet. Denne artikkelen forsøker å avklare disse spørsmålene og gir anbefalinger om hvordan norske domstoler bør behandle fremtidige saker om immunitet.

\section{Nøkkelord:}

folkerett, immunitet, sektormonisme, sivilprosess 
Innhold:

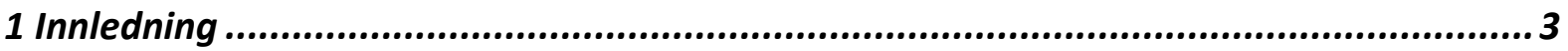

2 Folkerettens regler om statsimmunitet ............................................................. 4

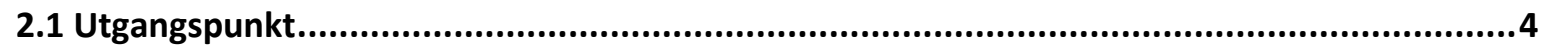

2.2 Unntak for kommersielle transaksjoner .....................................................................6

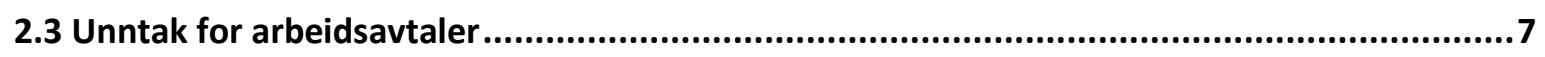

2.4 Unntak som ikke har vært oppe i norske domstoler.....................................................10

3. Folkerettens regler om diplomatisk immunitet .................................................... 11

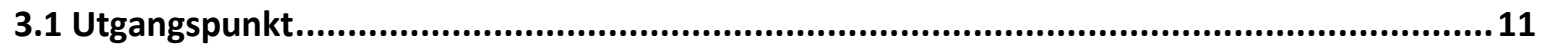

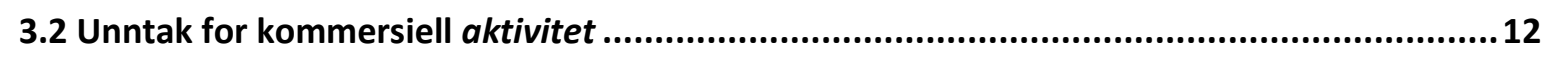

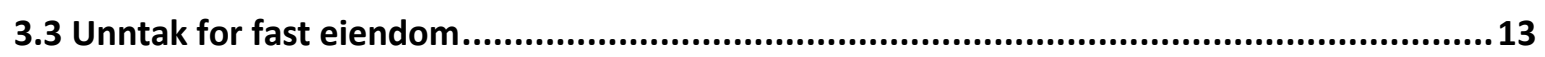

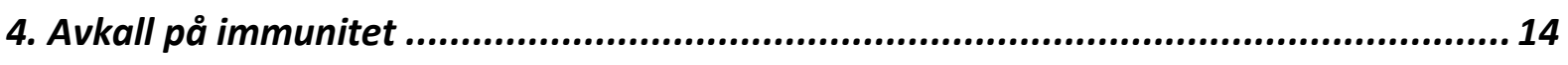

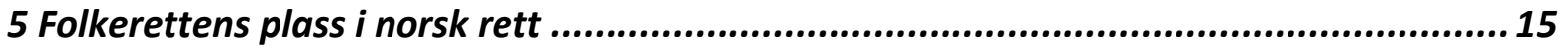

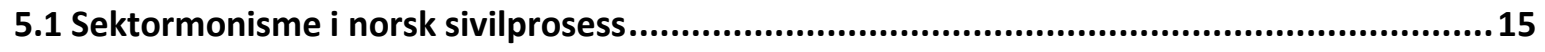

5.2 Immunitet som en absolutt prosessforutsetning ................................................................ 16

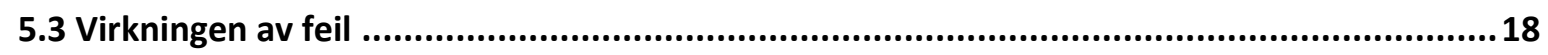

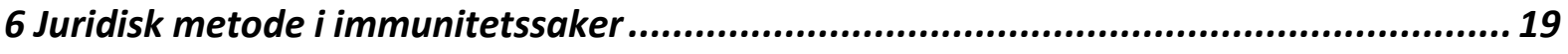

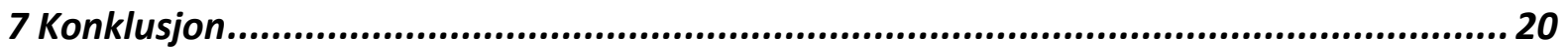




\section{1-1NNLEDNING}

Folkeretten har regler som gir stater og deres representanter immunitet $i$ andre staters nasjonale domstoler. Folkeretten er universell, så den er den samme for alle stater, men den gir samtidig den enkelte staten et visst spillerom med hensyn til hvordan reglene gjennomføres i nasjonal rett. ${ }^{1}$ Denne artikkelen behandler de folkerettslige immunitetsreglene og deres stilling i norsk sivilprosess.

Immunitetsreglene har vært oppe i norske domstoler i en lang rekke saker. Mye tyder på at dette er et utfordrende felt for domstolene. Flere avgjørelser har anvendt motstridende regler, gjerne uten å henvise til hverandre. Andre har lagt til grunn rettslige løsninger som avviker fra relevante folkerettslige regler. Det er derfor behov for en artikkel som gir en grundig gjennomgang av reglenes stilling og anvendelse i norsk rett.

Tvistelovens utgangspunkt er enkelt, uttrykt i § 1-2: Loven skal anvendes med de begrensningene som følger av folkeretten. Denne artikkelen viser at dette enkle utgangspunktet skjuler en rekke vanskelige og uavklarte spørsmål.

Artikkelen har fem hovedkapitler, i tillegg til innledningen og konklusjonen. De de to første handler om de folkerettslige reglene om henholdsvis statsimmunitet og diplomatisk immunitet, og hvordan de har blitt behandlet av norske domstoler (kapittel 2 og 3). Disse kapitlene dekker også unntak fra immunitetsreglene, som ofte er viktige i praksis. Deretter ser kapittel 4 nærmere på avkall på immunitet, som er aktuelt for både statsimmunitet og diplomatisk immunitet. Deretter behandles de folkerettslige reglenes formelle plass i norsk sivilprosess (kapittel 5) og noen spesielle metodespørsmål som oppstår i immunitetssaker (kapittel 6).

Statsimmunitet og diplomatisk immunitet tilkommer stater. Hva som er en stat, beror på en rettslig vurdering basert på kriterier som følger av folkerettslig sedvanerett. ${ }^{2}$ Anerkjennelse fra andre stater er ikke avgjørende for hva som er en stat i folkeretten. I norsk rett tilsier imidlertid Høyesteretts avgjørelse i Rt. 1938 s. 804 at norsk anerkjennelse er avgjørende for hva som etter norsk rett skal anses som en stat. I den saken kom Høyesterett til at Francoregimets ambassadør ikke kunne påberope seg immunitet fordi regjeringen han representerte ikke var anerkjent av Norge. ${ }^{3}$ Dermed vil for eksempel Kosovo ha immunitet i norsk rett, selv om det er omdiskutert om dette er en stat. ${ }^{4}$ Republikken Kina («Taiwan») og NordKypros, som Norge ikke anerkjenner, vil ikke ha immunitet.

Palestina er i en særstilling. Norge anerkjenner ikke staten Palestina. Den palestinske staten vil derfor ikke ha immunitet for norske domstoler. Det er uansett lite sannsynlig at dette kommer på spissen. Når Norge ikke har offisielle relasjoner med en stat, blir det få potensielle kontaktpunkter som kan føre til tvister for norske domstoler. Palestine Liberation Organization (PLO) representerer det palestinske folk i Norge. Norge og PLO har inngått en traktat som gir PLOs representasjon «samme privilegier og immunitet» som i VCDR. Traktaten sier ikke noe om statsimmunitet. Dermed vil norske domstoler gi PLOs

\footnotetext{
${ }^{1}$ Xiaodong Yang, State Immunity in International Law, Cambridge University Press 2012, s. 43.

2 James Crawford, The Creation of States in International Law, 2. utgave, Oxford University Press 2007, s. 27.

${ }^{3}$ Rt. 1938 s. 804 (s. 807).

${ }^{4}$ James Crawford, «Kosovo and the Criteria for Statehood in International Law», i Marko Milanovic og Michael Wood (red.), The Law and Politics of the Kosovo Advisory Opinion, Oxford University Press 2015, s. 280, 290; Milena Sterio, "The Case of Kosovo: Self-Determination, Secession, and Statehood Under International Law», Proceedings of the Annual Meeting (American Society of International Law), 2010 s. 361, på s. 364.
} 
representanter diplomatisk immunitet, men verken PLO eller den palestinske staten vil ha statsimmunitet.

I tillegg til statsimmunitet og diplomatisk immunitet, har folkeretten også regler om internasjonale organisasjoners immunitet. Reglene gir som regel immunitet for organisasjonen som sådan, for dens ansatte og bygninger og for diplomater som statene sender til organisasjonen. Reglene har stor praktisk betydning, siden alle organisasjoner driver sin virksomhet på territoriet til en eller flere stater. De følger av individuelle traktater for enkelt organisasjon, som for eksempel FNs Convention on the Privileges and Immunities of the United Nations. ${ }^{5}$ Innholdet i slike konvensjoner varierer. De har i liten grad vært et tema i norske domstoler.

\section{FOLKERETTENS REGLER OM STATSIMMUNITET}

\subsection{Utgangspunkt}

Folkerettens regler om statsimmunitet gir stater en rekke rettigheter overfor andre staters myndigheter. ${ }^{6}$ Staten selv kan i utgangspunktet ikke saksøkes i fremmede staters domstoler. ${ }^{7}$ Staters eiendom nyter også immunitet mot søksmål og tvangsmidler.

Statens representanter kan har immunitet mot søksmål, straffeforfølgning og tvangsmidler. Denne immuniteten har to ulike former. Noen representanter har immunitet ratione personae, som gir dem immunitet så lenge de innehar en bestemt stilling. De aktuelle personene kan i utgangspunktet ikke saksøkes eller straffes av andre stater så lenge de innehar stillingen, verken for offentlige eller private handlinger. Stillingene som omfattes er antagelig statsoverhodet, regjeringssjefen og utenriksministeren, men rettstilstanden er fremdeles noe usikker. ${ }^{8}$ I praksis betyr dette for eksempel at en annen stats sittende utenlandsk president ikke kan straffes for fyllekjøring i Norge. Alle statsrepresentanter har dessuten immunitet ratione materiae. Denne formen for immunitet dekker alle handlinger begått på vegne av staten. ${ }^{9}$ Personer som jobber for en stat kan derfor ikke straffes eller saksøkes i andre stater for handlinger begått på vegne av staten, selv etter at de har forlatt den aktuelle stillingen. De som kun har immunitet ratione materiae, har ikke immunitet for private handlinger, verken før eller etter at de forlater stillingen.

Reglene om statsimmunitet følger av folkerettslig sedvanerett. Noen av reglene er dessuten forsøkt kodifisert i United Nations Convention on Jurisdictional Immunities of States and Their Property fra 2004. Konvensjonen trer ikke i kraft før den har 30 parter. Per 2021 har den 20 parter, inkludert Norge. Konvensjonen er likevel relevant i spørsmål om folkerettslig

\footnotetext{
${ }^{5}$ Convention on the Privileges and Immunities of the United Nations, 13. februar 1946, 1 UNTS 15.

${ }^{6}$ Jurisdictional Immunities of the State (Germany v. Italy: Greece intervening), Judgment, I.C.J. Reports 2012, p. 99, 123; Xiaodong Yang, State Immunity in International Law, Cambridge 2012, s. 34.

${ }^{7}$ United Nations Convention on Jurisdictional Immunities of States and Their Property, 2. desember 2004, FNs generalforsamling resolusjon 59/38, artikkel 5 .

${ }^{8}$ Arrest Warrant of 11 April 2000 (Democratic Republic of the Congo v. Belgium), Judgment, I.C.J. Reports 2002, p. 3, 21; Certain Questions of Mutual Assistance in Criminal Matters (Djibouti v. France), Judgment, I.C.J. Reports 2008, p. 177, 236-237.

${ }^{9}$ James Crawford, Brownlie's Principles of Public International Law, 9. utgave, Oxford University Press 2019, s. 477; Hazel Fox og Philippa Webb, The Law of State Immunity, 3. utgave, Oxford University Press 2015, s. 570 .
} 
immunitet så langt dens bestemmelser reflekterer folkerettslig sedvanerett. ${ }^{10}$ Regjeringen antok i forbindelse med Norges ratifikasjon av konvensjonen at den «[1]angt på vei [var] en kodifisering av det som i dag må anses å være gjeldende folkerettslig sedvanerett». ${ }^{11}$ Den har dessuten blitt anvendt av ulike nasjonale domstoler. ${ }^{12}$ Ulike forfattere legger også til grunn av konvensjonen reflekterer sedvanerett. ${ }^{13}$ Uenighetene rundt konvensjonen handler først og fremst om hva den ikke dekker. ${ }^{14}$ Den gjelder ikke immunitet i straffesaker, siden den kun gjelder sivile saker. Konvensjonen sier ikke noe om immunitet for statens representanter, kun for staten selv om og dens eiendom. Den sier ikke noe særskilt om militære styrker, som har en egen immunitet nedfelt i Gèneve-konvensjonene. ${ }^{15}$ Den sier heller ikke om hvorvidt det finnes unntak for immunitet ved særlig alvorlige forbrytelser, som folkemord eller tortur. Det tryggeste for norske domstoler vil være å legge til grunn at konvensjonens innhold reflekterer folkerettslig sedvanerett, selv om den ikke dekker hele sedvaneretten om statsimmunitet. Siden konvensjonen ikke har trådt i kraft, kan domstolene kun anvende sedvanerett reflektert i konvensjonen, slik lagmannsretten gjorde i LB-2015-104460. ${ }^{17}$ Denne artikkelen viser til konvensjonen, og holder norsk rettspraksis, fra både før og etter 2004, opp mot konvensjonens bestemmelser.

Ved ratifiseringen av konvensjonen ga Norge en offisiell erklæring om konvensjonens anvendelse. Slike erklæringer har ikke noen formell rettsvirkning. ${ }^{18}$ Det er $i k k e$ snakk om en reservasjon. Reservasjoner innebærer at en stat tar forbehold knyttet til bestemmelser i en traktat, som andre parter kan velge å godta eller avslå. Reservasjoner til traktater har rettsvirkninger og er regulert i Wien-konvensjonen om traktatretten artikkel 19-23. Tolkningserklæringer, som den Norge har avgitt for FN-konvensjonen, gir kun uttrykk for den enkelte statens tolkning av en traktat. De øvrige partene er ikke bundet av dette.

Norges erklæring presiserer at Norge tolker konvensjonen slik at den ikke gjelder for militær virksomhet. Ifølge erklæringen skal konvensjonen heller ikke gjelde i tilfeller der man har et «special immunity regime», herunder immunitet ratione personae. Man kan innvende at ratione personae ikke er noe mer «special» enn ratione materiae, og at de to regelsettene gjelder om hverandre. Det er ikke klart hva dette punktet i Norges erklæring er ment å innebære for anvendelsen av konvensjonen. Neste avsnitt sier at artikkel 18 bør tolkes slik at en stat ikke har immunitet mot tvangstiltak i forkant av en rettsavgjørelse mot en eiendom som en stat bruker til noe annet enn «government non-commercial purposes». Dette kan for eksempel gjelde et statlig selskap som bruker en kontorbygning i næringsvirksomhet, der det blir tvist om bruken av bygningen, og motparten krever at selskapets ansatte ikke skal ha adgang til bygningen frem til en dom er avsagt. Norge mener altså at immunitet ikke skal være til hinder for at en slik forføyning kan gis. Ordlyden i artikkel 18 skiller ikke mellom

${ }^{10}$ Jurisdictional Immunities of the State (Germany v. Italy: Greece intervening), Judgment, I.C.J. Reports 2012, p. $99,128$.

${ }^{11}$ St. Prp. nr. 33 (2005-06) s. 2.

${ }^{12}$ Xiaodong Yang, State Immunity in International Law, Cambridge University Press 2012, s. 454 nevner en lang rekke saker fra England, i tillegg til en sak fra Norge (RG 2001 s. 940).

${ }^{13}$ For eksempel Xiaodong Yang, State Immunity in International Law, Cambridge University Press 2012, s. 441 og 455.

${ }^{14}$ Hazel Fox og Philippa Webb, The Law of State Immunity, 3. utgave, Oxford University Press 2015, s. 324325; Xiaodong Yang, State Immunity in International Law, Cambridge University Press 2012, s. 456.

${ }^{15}$ Convention relative to the Treatment of Prisoners of War, 12. august 1949, 75 UNTS 135, Artikkel 87;

Protocol Additional to the Geneva Conventions of 12 August 1949, and relating to the Protection of Victims of International Armed Conflicts, 8. juni 1977, 1125 UNTS 3, Artikkel 43(2).

${ }^{17}$ Morten Ruud og Geir Ulfstein, Innføring i folkerett, 5. utgave, Universitetsforlaget 2018, s. 183.

${ }^{18}$ James Crawford, Brownlie's Principles of Public International Law, 9. utgave, Oxford University Press 2019, s. 361. 
eiendom som brukes til kommersiell eller offentlig virksomhet, og gir i utgangspunktet all slik eiendom immunitet mot tvangstiltak i forkant av en rettssak. Til slutt sier Norges erklæring at konvensjonen skal være «without prejudice to any future international development in the protection of human rights». Dette siste må forstås som en henvisning til muligheten for å gjøre unntak fra statsimmunitet i saker om alvorlige menneskerettighetsbrudd, som diskuteres i kapittel 2.4. Ingen av forholdene som berøres $i$ den norske tolkningserklæringen har så langt kommet på spissen i norske domstoler.

Det finnes også en European Convention on State Immunity (ECSI) fra $1972 .{ }^{19}$ Denne har åtte parter, og Norge er ikke én av dem, men konvensjonen har likevel hatt stor betydning for utviklingen i nasjonal rettspraksis i mange land. ${ }^{20}$ Dessuten finnes det en traktat fra 1926 om immunitet for statsskip, som Norge har sluttet seg til. ${ }^{21}$

\subsection{Unntak for kommersielle transaksjoner}

Utgangspunkt om at stater har statsimmunitet, har et unntak for kommersielle transaksjoner. Dette støttes blant av praksis Den internasjonale domstolen (ICJ). ${ }^{22} \mathrm{FN}-k$ onvensjonen artikkel 10(1) sier, i tråd med dette, at immunitet ikke gjelder for krav knyttet til «a commercial transaction». ${ }^{23}$ Begrepet «commercial transaction» defineres nærmere i artikkel 2(c), der den mest sentrale er punkt (i) om «any commercial contract or transaction for the sale of goods or supply of services». Denne regelen har blitt anvendt av en lang rekke nasjonale domstoler. ${ }^{24}$

Regelen har blant annet blitt anvendt av norske domstoler. RG 2001 s. 940 var en sak mellom USA og et norsk selskap, der selskapet krevde tilbake et pengebeløp de feilaktig hadde betalt til ambassaden. Retten drøftet om kravet hadde «utspring i et kontraktsforhold», og konkluderte med at det var tilfelle, og at USA derfor ikke hadde immunitet. Dette var en riktig anvendelse av folkerettens regler, siden retten fokuserte på den konkrete kontraktsforholdet.

Også LE-1992-339 anvendte reglene korrekt. Saken sto mellom Sør-Afrika og et norsk selskap, der selskapet hadde gått til sak med et krav om erstatning etter å ha avtalt å utføre byggearbeider på Sør-Afrikas ambassadebygning i Oslo. Retten tok utgangspunkt at statsimmunitet gjelder «statens handlinger som stat», og at Sør-Afrika ikke hadde statsimmunitet i den aktuelle sakene. Her fokuserte altså retten på den bestemte handlinger, som er i tråd med FN-konvensjonens ordlyd.

I Rt. 1936 s. 136 og Rt. 1936 s. 874 kom Høyesterett til at norske domstoler kunne behandle saker mot Sovjetunionens handelsrepresentasjon. ${ }^{25}$ Sakene gjaldt certepartier, som må regnes som et privatrettslig forhold, men Høyesterett sa ikke dette uttrykkelig. At det ikke forelå

\footnotetext{
${ }^{19}$ European Convention on State Immunity, 16. juni 1972, 1495 UNTS 181.

${ }^{20}$ Hazel Fox og Philippa Webb, The Law of State Immunity, 3. utgave, Oxford University Press 2015, s. 118.

${ }^{21}$ International Convention for the Unification of Certain Rules relating to the Immunity of State-owned Vessels, 10 april 1926, 176 LNTS 199 (med Additional Protocol, 24. may 1934).

${ }^{22}$ Jurisdictional Immunities of the State (Germany v. Italy: Greece intervening), Judgment, I.C.J. Reports 2012, p. 99, 124-125.

${ }^{23}$ ECSI har unntak fra statsimmunitet for ulike kommersielle forhold i artikkel 4, 6, 7 og 8 .

${ }^{24}$ Hazel Fox og Philippa Webb, The Law of State Immunity, 3. utgave, Oxford University Press 2015, s. 324.

${ }^{25}$ Rt. 1936 s. 136 (s. 137). Jurisdiksjonsspørsmålet ble ikke diskutert i den andre dommen.
} 
immunitet i saken, kunne også baseres på en traktat mellom Norge og Sovjetunionen. ${ }^{26}$ Det er derfor vanskelig å utlede noe om immunitet fra disse avgjørelsene.

Ordlyden i FN-konvensjonen skiller seg fra ordlyden i det lignende unntaket i VCDR (som gjelder kommersiell aktivitet snarere enn transaksjoner). Dette skillet gjennomgås nærmere i kapittel 3.2 nedenfor.

\subsection{Unntak for arbeidsavtaler}

FN-konvensjonen har en egen bestemmelse om arbeidsavtaler i artikkel $11 .{ }^{27}$ Der er utgangspunktet i punkt (1) at en stat ikke har immunitet for søksmål i en annen stats domstoler $i$ en tvist om en arbeidsavtale som går ut på at en person skal jobbe i den andre staten. Et klassisk eksempel er at der en stat har ansatt en lokal arbeidstaker som skal jobbe ved statens ambassade $i$ en annen stat, og deretter avskjediget arbeidstakeren, som går til sak for de lokale domstolene med påstand om at avskjedigelsen er ugyldig.

FN-konvensjonen artikkel 11(2) angir et unntak fra utgangspunktet nevnt ovenfor. Når et av punkene i (2) er oppfylt, har altså staten immunitet likevel. Punkt (2) nevner blant annet personer som «perform particular functions in the exercise of governmental authority» (bokstav a) og diplomatiske og konsulære tjenestemenn (bokstav b og c). Den nevner dessuten saker om ansettelse eller gjeninnsettelse av en arbeidstaker eller fornyelse av en arbeidskontrakt (bokstav c), oppsigelsessaker der en rettssak «would interfere with» statens «security interests» (bokstav d), personer som er både statsborgere i og ansatt av den fremmede staten og ikke har permanent opphold i domstolens hjemstat (bokstav e) og saker der arbeidsgiver og arbeidstaker skriftlig har avtalt at saken ikke hører hjemme i de lokale domstolene (bokstav f).

Arbeidsrettssaker der immunitet er aktuelt, handler ofte lokalt ansatte ved ambassader, og slike saker pleier å anlegges i staten der ambassaden ligger. Lokalt ansatte utfører normalt ikke tradisjonelle diplomatiske oppgaver, og hvis man anvender FN-konvensjonen artikkel 11(2)(a), blir et viktig spørsmål om de utøver «governmental authority». Det er vanskelig å påvise en konsekvent praksis mellom ulike nasjonale domstoler i denne typen saker. ${ }^{28}$ Saker med lignende faktum har fătt ulikt utfall. ${ }^{29}$ I Sengupta-saken fra 1982 mente Englands Employment Appeal Tribunal at alle ansatte ved ambassader utøver offentlig myndighet på vegne av staten. ${ }^{30}$ Avgjørelsen ble avsagt lenge før FN-konvensjonen ble vedtatt, men den omhandler samme spørsmål som artikkel 11(2)(a). Yang nevner en rekke yrkesgrupper ved ambassader, som sjåfører, tolker, sekretærer, resepsjonister og lagerarbeidere, der ulike nasjonale domstoler har kommet til ulike resultater for samme yrkesgruppe. ${ }^{31} \mathrm{Et}$ utgangspunkt kan finnes i FN-konvensjonens ordlyd «particular functions», som tilsier at

\footnotetext{
${ }^{26}$ Ivar Alvik, «Statsimmunitet etter norsk rett og folkeretten», i i Ole Kristian Fauchald, Henning Jakhelln og Aslak Syse (red.), Dog fred er ej det bedste: festskrift til Carl August Fleischer, Universitetsforlaget 2006, s. 13, 21.

${ }^{27}$ I ECSI er arbeidsavtaler dekket i artikkel 5. Der er utgangspunktet i artikkel 5(1) at staten ikke har immunitet dersom arbeidet skal utføres i den staten der saken reises. Artikkel 5(2) angir unntak fra dette, der arbeidstakeren er statsborger av den saksøkte staten, eller ikke var statsborger eller bosatt i staten der saken reises eller der partene har avtalt noe annet.

${ }^{28}$ Hazel Fox og Philippa Webb, The Law of State Immunity, 3. utgave, Oxford University Press 2015, s. 443 ser «no uniformity» i saker før vedtakelsen av FN-konvensjonen; Xiaodong Yang, State Immunity in International Law, Cambridge University Press 2012, s. 164.

${ }^{29}$ Xiaodong Yang, State Immunity in International Law, Cambridge University Press 2012, s. 196.

${ }^{30}$ Employment Appeal Tribunal, Sengupta v. Republic India, 17. november 1982.

${ }^{31}$ Xiaodong Yang, State Immunity in International Law, Cambridge University Press 2012, s. 133, 182 og 196.
} 
man skal fokusere på konkrete arbeidsoppgaver snarere enn de øvrige rammene for arbeidet. $^{32}$

At en domstol gir en stat immunitet i en slik sak, kan uansett innebære et brudd på saksøkerens rett til domstolsadgang etter EMK artikkel 6. Dette har vært oppe for Den europeiske menneskerettsdomstolen (EMD) i flere saker. I slike saker har EMD også anvendt innholdet i FN-konvensjonen artikkel 11, selv i saker med stater som ikke har ratifisert konvensjonen. ${ }^{33}$ Dette kan tas til støtte for at artikkel 11 reflekterer sedvanerett. FNkonvensjonen artikkel 26 sier at konvensjonens bestemmelser ikke skal påvirke rettigheter og plikter «under existing international agreements». EMK er en slik eksisterende traktat. EMD antar at EMK setter en grense for anvendelsen av FN-konvensjonen, og det stemmer med bestemmelsen i artikkel 26.

EMD har særlig vært opptatt av FN-konvensjonen artikkel 11(2)(a), og tolkningen av «exercise of governmental authority». EMD har i ulike saker konkludert med at stater har tolket dette begrepet for vidt, og dermed gitt stater immunitet i saker der de ikke hadde krav på det, i strid med klageres rett til domstolsadgang etter EMK artikkel 6. EMD godtar ikke at nasjonale domstoler uten videre legger til grunn at enhver stilling ved en ambassade er utøver offentlig myndighet. ${ }^{34}$ Det må gjøres en konkret vurdering av den enkelte arbeidstakerens oppgaver. EMD mener at FN-konvensjonen artikkel 11(2)(a) må tolkes strengt, ${ }^{35}$ og har dessuten oppstilt en presumsjon for at staten ikke har immunitet i saker som gjelder «administrative and technical staff». ${ }^{36}$ Arbeidstakere som ifølge EMD ikke har utøvd offentlig myndighet har vært en regnskapsfører, ${ }^{37}$ en fotograf,,${ }^{38}$ to sikkerhetsvakter, ${ }^{39} \mathrm{en}$ protokollspesialist og tolk ${ }^{40}$ og en resepsjonist og tolk som senere ble forfremmet til kulturog informasjonsarbeider. ${ }^{41}$ Alle disse arbeidstakerne var ansatt ved ambassader. EMD har imidlertid ikke oppstilt klare vurderingskriterier som kan brukes for å vurdere om en arbeidstaker har utøvd «governmental authority». I de nevnte sakene har EMD nøyd seg med å slå fast at arbeidstakerne «clearly» ikke var omfattet at FN-konvensjonen artikkel 11(2)(a), etter at den innklagede statens domstoler ikke hadde behandlet spørsmålet grundig nok.

I én sak, Cudak mot Litauen, anvendte EMD et utkast til FN-konvensjonen artikkel 11(2)(a), som hadde ordene «closely related to» foran «the exercise of governmental authority». Dette kan oppfattes som en høyere terskel sammenlignet med den endelige ordlyden $\mathrm{i}$

\footnotetext{
32 Joanne Foakes og Roger O'Keefe, 'Article 11', i Roger O'Keefe, Christian J. Tams og Antonios Tzanakopoulos (red.), The United Nations Convention on Jurisdictional Immunities of States and Their Property: A Commentary, Oxford University Press 2013, s. 183, 200.

${ }^{33}$ Hazel Fox og Philippa Webb, The Law of State Immunity, 3. utgave, Oxford University Press 2015, s. 451; for eksempel EMDs dom 17. juli 2012 Wallishauser mot Østerrike (saksnummer 156/04).

${ }^{34}$ EMDs dom av 25. oktober 2016 Radunović mfl. mot Montenegro (saksnumre 45197/13, 53000/13 og 73404/13) avsnitt 80-82; EMDs dom av 8. november 2016 Naku mot Litauen og Sverige (saksnummer 26126/07) avsnitt 95.

${ }^{35}$ EMDs dom av 25. oktober 2016 Radunović mfl. mot Montenegro (saksnumre 45197/13, 53000/13 og $73404 / 13$ ) avsnitt 80.

${ }^{36}$ EMDs dom av 23. mars 2010 Cudak mot Litauen (saksnummer 15869/02) avsnitt 66.

${ }^{37}$ EMDs, dom av 29. juni 2011 Sabeh El Leil mot Frankrike (saksnummer 34869/05).

${ }^{38}$ EMDs dom av 17. juli 2012, Wallishauser mot Østerrike (saksnummer 156/04).

${ }^{39}$ EMDs dom av 25. oktober 2016 Radunović mfl. Mot Montenegro (saksnumre 45197/13, 53000/13 og 73404/13).

${ }^{40}$ EMDs dom av 25. oktober 2016 Radunović mfl. mot Montenegro (saksnumre 45197/13, 53000/13 og 73404/13).

${ }^{41}$ EMDs dom av 8. november 2016 Naku mot Litauen og Sverige (saksnummer 26126/07).
} 
bestemmelsen, men EMD kommenterte ikke dette nærmere. ${ }^{42}$ Domstolen nevnte den ansattes konkrete arbeidsoppgaver, «recording international conversations, typing, sending and receiving faxes, photocopying documents, providing information and assisting with the organisation of certain events», og mente at dette «objectively» ikke var omfattet av bestemmelsen. ${ }^{43}$ Dette er dermed eksempler på oppgaver som etter EMDs syn ikke innebærer utøvelse av offentlig myndighet.

En vurdering av om en arbeidstaker utøver offentlig myndighet, bør fokusere på om arbeidstakeren utfører oppgaver som er særegne for en stat. Det at en arbeidsoppgave også uføres av ansatte i private selskaper, er et argument for at den ikke innebærer utøvelse av offentlig myndighet.

Det er mulig å hevde at EMD har gått for langt i favør av å nekte immunitet i sin tolkning av FN-konvensjonen artikkel 11. ${ }^{44}$ Det tryggeste for norske domstoler vil likevel være å følge EMDs praksis der den er relevant. Norske domstoler bør altså legge FN-konvensjonen til grunn, gjøre en individuell vurdering av hver enkelt arbeidstaker når de anvender artikkel 11(2)(a) og være tilbakeholdne med å tilstå immunitet i saker som gjelder administrativ og teknisk personale ved ambassader.

Norske domstoler har allerede behandlet flere saker om arbeidsavtaler. Den viktigste er Rt. 2004 s. 402, der en sjåfør hadde blitt avskjediget fra USAs ambassade og gikk til sak. Høyesteretts kjæremålsutvalg tok som utgangspunkt at USA hadde statsimmunitet, men at det gjaldt et skille «mellom handlinger som er utslag av myndighetsutøvelse og handlinger av privatrettslig karakter», og at immunitet kun gjaldt førstnevnte. ${ }^{45}$ Kjæremålsutvalget la til grunn at ansettelse ved en ambassade innebærer myndighetsutøvelse. ${ }^{46}$ Kjæremålsutvalgets fremgangsmåte på dette punktet er ikke i tråd med FN-konvensjonen artikkel 11, slik denne tolkes av EMD. Som nevnt ovenfor, har EMD avvist en slik generell antagelse om at alle ansatte ved en ambassade utøver offentlig myndighet. Det avgjørende skal i stedet være om den enkelte arbeidstakeren har utøvd «governmental authority». Rt. 2004 s. 402 ble riktignok avgjort noen måneder før FN-konvensjonen ble vedtatt, men konvensjonen var ment å kodifisere gjeldende folkerettslig sedvanerett. I RG 2001 s. 940 viste lagmannsretten til et «utkast» til konvensjonen, og det kunne Høyesteretts kjæremålsutvalg også gjort.

Også i NAD-1981-634 anvendte retten feil utgangspunkt for en tilsvarende drøftelse. Retten vurderte hvorvidt et italiensk kulturinstitutt drev offentlig virksomhet eller næringsvirksomhet. Dette ville vært riktig hvis hadde saken hadde handlet om diplomatisk immunitet, jf. kapittel 3 nedenfor. Retten burde i stedet vurdert om den ansatte som gikk til sak hadde utøvd offentlig myndighet.

Norske domstoler bør derfor ikke følge utgangspunktet i Rt. 2004 s. 402 om at ansettelse ved en ambassade innebærer utøvelse av offentlig myndighet. Domstolene bør heller bruke samme utgangspunkt som lagmannsretten i LB-2015-104460. Der gjorde retten en konkret

\footnotetext{
42 Joanne Foakes og Roger O'Keefe, 'Article 11', i Roger O'Keefe, Christian J. Tams og Antonios Tzanakopoulos (red.), The United Nations Convention on Jurisdictional Immunities of States and Their Property: A Commentary, Oxford University Press 2013, s. 183, 199-200.

${ }^{43}$ EMDs dom av 23. mars 2010 Cudak mot Litauen (saksnummer 15869/02), avsnitt 70.

${ }^{44}$ Lisa Rodgers, «State immunity and employment relationships before the European Court of Human Rights», 2019, ERA Forum, s. 537, 549.

${ }^{45}$ Rt. 2004 s. 402 avsnitt 20.

${ }^{46}$ Rt. 2004 s. 402 avsnitt 25.
} 
vurdering av om en enkelt sikkerhetsvakt utøvde offentlig myndighet på vegne av staten han hadde vært ansatt for. Dette utgangspunkt er et annet enn det i Rt. 2004 s. 402, men det er riktig ifølge EMD. ${ }^{47}$

Lagmannsretten i LB-2015-104460 kom til at sikkerhetsvakten hadde utøvd offentlig myndighet og at staten hadde immunitet. EMD kom derimot i Radunovic and Others $v$. Montenegro til at en saksøkt stat ikke skulle hatt statsimmunitet i en sak om oppsigelse av nettopp en sikkerhetsvakt. Hvis saksøkeren i LB-2015-104460 hadde tatt saken videre til EMD, ville EMD antagelig fulgt sin tidligere praksis, og konkludert med at Norge hadde brutt EMK artikkel 6. Selv om lagmannsretten anvendte riktig utgangspunkt, kom de til feil resultat, iallfall ifølge EMDs praksis.

\subsection{Unntak som ikke har vært oppe i norske domstoler}

Det finnes ytterligere unntak fra statsimmunitet som ikke har vært oppe i norske domstoler.

FN-konvensjonen sier ikke noe om at det kan gjøres unntak fra immunitetsreglene ved anklager om alvorlige menneskerettighetsbrudd. Partene ble ikke enige om å ta inn dette da FN-konvensjonen ble utarbeidet. ${ }^{48}$ Norge og de øvrige nordiske statene har lenge støttet et slikt unntak, blant annet gjennom arbeid i FN. ${ }^{49}$ ICJ har ikke klart å påvise slike unntak i gjeldende rett, verken i Jurisdictional Immunities of the State (om staters immunitet) eller i Arrest Warrant (om utenriksministres immunitet). ${ }^{50}$ Norges tolkningserklæring til FNkonvensjonen nevner «future international development in the protection of human rights». Siden ICJ har avvist at slike unntak eksisterer, er det naturlig at Norges tolkningserklæring begrenser seg til å nevne «future developments». Et bidrag til slike «developments» kan komme fra FNs folkerettskommisjon, som blant annet jobber med et prosjekt om immunitet $\mathrm{i}$ straffesaker for statsansatte. ${ }^{51}$ Kommisjonen har foreløpig vedtatt et punkt som gjør unntak fra immunitet ratione materiae i straffesaker for folkemord, forbrytelser mot menneskeheten, krigsforbrytelser, apartheid, tortur og tvungen forsvinning. ${ }^{52}$ Et mindretall i kommisjonen var imidlertid sterkt kritiske til vedtaket. ${ }^{53}$

Dersom et spørsmål om immunitet skulle komme opp i en sak om alvorlige menneskerettighetsbrudd for norske domstoler, bør domstolen følge ICJs praksis og ikke oppstille et generelt unntak fra immunitet. Det vil imidlertid være mulig å gjøre unntak fra immunitet basert på konkrete rettskilder som er relevante i den aktuelle saken. Det gjorde House of Lords i Pinochet-saken. Der brukte seks av syv dommere FNs torturkonvensjon som grunnlag for å konkludere med at Augosto Pinochet ikke hadde immunitet for britiske

\footnotetext{
${ }^{47}$ Morten Ruud og Geir Ulfstein, Innføring i folkerett, 5. utgave, Universitetsforlaget 2018, s. 186 ser ut til å være enige i dette.

${ }^{48}$ Hazel Fox og Philippa Webb, The Law of State Immunity, 3. utgave, Oxford University Press 2015, s. 324325.

49 Jf. for eksempel Øyvind Hernes, «Statement by the Nordic countries: Denmark. Finland. Iceland. Norway and Sweden», FNs generalforsamling sjette komité, 1. November 2020.

${ }^{50}$ Jurisdictional Immunities of the State (Germany v. Italy: Greece intervening), Judgment, I.C.J. Reports 2012, p. 99, 139; Arrest Warrant of 11 April 2000 (Democratic Republic of the Congo v. Belgium), Judgment, I.C.J. Reports 2002, p. 3, 24.

${ }^{51}$ International Law Commission, «Immunity of State officials from foreign criminal jurisdiction» (2021) $<$ legal.un.org/ilc/guide/4_2.shtml $>$.

${ }^{52}$ United Nations, Report of the International Law Commission, Sixty-ninth session (2017, A/72/10) s. 177.

${ }^{53}$ United Nations, Report of the International Law Commission, Sixty-ninth session (2017, A/72/10) s.181-183.
} 
domstoler for visse anklager om at han som chilensk president var ansvarlig for tortur mot politiske motstandere. ${ }^{54}$

Et annet unntak fra statsimmunitet gjelder fast eiendom. I FN-konvensjonen finnes dette unntaket i artikkel 13. Den mest praktiske bestemmelsen er artikkel 13(a), som sier at stater ikke har immunitet for søksmål i andre staters domstoler i saker om fast eiendom i den andre staten. ${ }^{55}$ Unntaket er også en etablert del av folkerettslig sedvanerett. ${ }^{56}$

Andre unntak i FN-konvensjonen er for erstatningsbetingende handlinger på en fremmed stats territorium (artikkel 12), saker om saker om immaterielle rettigheter (artikkel 14), saker der staten deltar i en sammenslutning (artikkel 15), og visse saker om statsskip (artikkel 16). Disse unntakene har foreløpig heller ikke vært oppe i norske domstoler.

Unntakene i artikkel 12 til 16 gjelder kun søksmål. De gjør ikke unntak fra immuniteten for tvangstiltak, heller ikke der slike tiltak har tilknytning til et søksmål der et av unntakene kommer til anvendelse.

\section{FOLKERETTENS REGLER OM DIPLOMATISK IMMUNITET}

\subsection{Utgangspunkt}

I folkeretten har personer og eiendeler som er involvert $\mathrm{i}$ en stats diplomatiske og konsulære virksomhet immunitet overfor andre stater. Dette er regulert i henholdsvis Vienna Convention on Diplomatic Relations (VCDR) og Vienna Convention on Consular Relations (VCCR). ${ }^{57}$ Norge er part i begge. Dette kapitlet henviser til bestemmelsene i VCDR. Reglene i VCCR er i stor grad tilsvarende.

Ansatte ved ambassader og konsulater har ulike former for immunitet overfor sine mottakerstater. Diplomatiske tjenestemenn, altså de faglig ansatte ved ambassadene, kan i utgangspunktet ikke pågripes eller utsettes for tvangsmidler, jf. VCDR artikkel 29. De kan heller ikke saksøkes for mottakerstatens domstoler, jf. VCDR artikkel 31(1). VCDR artikkel 31(1) har tre unntak: visse saker om fast eiendom (bokstav a), visse arverettssaker (bokstav b) og saker om kommersielle aktivitet (bokstav c). Disse gjennomgås i underkapitlene nedenfor. I disse unntakstilfellene er dessuten immuniteten mot tvangsjurisdiksjon begrenset, jf. artikkel 31(3). ${ }^{58}$

Andre ansatte ved en ambassade, og familiene til de ansatte, har varierende grader av immunitet. Dette reguleres nærmere i VCDR artikkel 37.

\footnotetext{
${ }^{54}$ Se kommentar i Andrea Bianchi, «Immunity versus Human Rights: The Pinochet Case», 1999, European Journal of Internatonal Law, s. 237, 249.

${ }^{55}$ ECSI har unntak fra statsimmunitet for fast eiendom i artikkel 9-10.

${ }^{56}$ Hazel Fox og Philippa Webb, The Law of State Immunity, 3. utgave, Oxford University Press 2015, s. 443 ser «no uniformity» i saker før vedtakelsen av FN-konvensjonen; Xiaodong Yang, State Immunity in International Law, Cambridge University Press 2012, s. 426.

${ }^{57}$ Vienna Convention on Diplomatic Relations, 18. april 1961, 500 UNTS 95; Vienna Convention on Consular Relations, 24. april 1963, 596 UNTS 261

${ }^{58}$ Dette behandles nærmere av for eksempel Eileen Denza, Diplomatic Law: Commentary on the Vienna

Convention on Diplomatic Relations, 4. utgave, Oxford University Press 2016, s. 264-265.
} 
VCDR artikkel 22 gir ambassadens bygninger immunitet mot mottakerstaten tvangsjurisdiksjon. VCDR Artikkel 22(1) sier at ambassadeeiendom «shall be inviolable», altså ukrenkelig. Artikkel 22(3) utdyper dette, ved å si at eiendommen «shall be immune from search, requisition, attachment or execution». Etter sin ordlyd gir artikkel 22 eiendommen immunitet mot tvangsfullbyrdelse, men den gir ikke staten immunitet mot søksmål om krav knyttet til ambassadeeiendommen. ${ }^{59}$ «Search» er ransaking i eiendommen, «requisition» og «attachment» viser til beslag i eiendommen, mens «execution» handler om å involvere eiendommen fullbyrdelsen av en dom. Bestemmelsens ordlyd forbyr derimot ikke å ta ut sivilt søksmål mot staten i en sak som dreier seg om ambassadeeiendommen.

Immunitet mot tvangsjurisdiksjon gjelder også for diplomatiske tjenestemenns privatbolig, jf. artikkel 30. Ambassadens kjøretøy, arkiver og postsendinger har også immunitet, jf. artikkel $24 \operatorname{og} 27$.

Det er viktig å skille mellom statsimmunitet og diplomatisk immunitet. ${ }^{60}$ Statsimmunitet gir en generell beskyttelse til staten som rettssubjekt og til dens eiendeler og representanter. Diplomatisk immunitet beskytter en snever gruppe av statens representanter og eiendeler. De to regelsettene overlapper i noen grad. Diplomater er statsansatte, og ambassadebygninger er ofte eid av den aktuelle staten. Da har de statsimmunitet i tillegg til diplomatisk immunitet. Virkeområdet for statsimmunitet er mye bredere enn for diplomatisk immunitet. Diplomatisk immunitet er likevel praktisk viktig, fordi ambassadevirksomhet er den mest utbredte virksomheten stater driver på andre staters territorium. Diplomater kommer derfor i kontakt med fremmede staters rettssystemer langt oftere enn andre statsansatte, både privat og $\mathrm{i}$ embets medfør.

LE-1992-339 dette skillet mellom statsimmunitet og diplomatisk immunitet på riktig måte. Saken gjaldt et søksmål om betaling for arbeid på en ambassade. Retten tok kun stilling til om den saksøkte staten (Sør-Afrika) hadde statsimmunitet. Lagmannsretten bemerket at «[s]taters immunitet omhandles ikke i Wien-konvensjonen». Et eksempel på en avgjørelse som $i k k e$ anvendte skillet korrekt, er LB-2016-50175, som er nærmere omtalt i kapittel $3.2 \mathrm{og}$ 3.3 nedenfor.

\subsection{Unntak for kommersiell aktivitet}

Et unntak fra diplomatiske tjenestemenns immunitet mot søksmål gjelder kommersiell virksomhet. Dette følger av VCDR artikkel 31(1)(c), som sier at diplomatisk immunitet ikke gjelder for krav knyttet til «professional or commercial activity». Det avgjørende er om staten eller diplomaten driver en form for forretningsvirksomhet på siden av ambassadevirksomheten. ${ }^{61}$ Diplomatisk immunitet gjelder ikke for søksmål om krav knyttet til slik virksomhet.

VCDR artikkel 31(1)(c) har en annen ordlyd enn den lignende regelen FN-konvensjonen om statsimmunitet artikkel 10(1) jf. 2(c)(i). De to instrumentene handler om henholdsvis «transaction» (statsimmunitet) og «activity» (diplomatisk immunitet). Disse begrepene har forskjellig innhold. Statsimmunitet har et vurderingstema som knytter seg til en bestemt

\footnotetext{
${ }^{59}$ Eileen Denza, Diplomatic Law: Commentary on the Vienna Convention on Diplomatic Relations, 4. utgave, Oxford University Press 2016, s. 126-127.

${ }^{60}$ Rosanne van Alebeek og Riccardo Pavoni, «Immunities of States and their Officials», i André Nollkaemper mfl. (red.), International Law in Domestic Courts: A Casebook, Oxford University Press 2018, s. 100, 135.

${ }^{61}$ Eileen Denza, Diplomatic Law: Commentary on the Vienna Convention on Diplomatic Relations, 4. utgave, Oxford University Press 2016, s. 251.
} 
transaksjon. Diplomatisk immunitet handler mer generelt om en virksomhet. Norsk underrettspraksis har flere ganger trått feil i anvendelsen av disse reglene.

LB-2016-50175 drøftet diplomatisk immunitet og pekte på at et krav om ubetalt leie for en ambassadeeiendom var «et rent privatrettslig spørsmål». Ved diplomatisk immunitet er det imidlertid virksomhetens art som er avgjørende. En leieavtale må i denne sammenhengen regnes som en transaksjon, ikke en virksomhet. Ambassaden driver ambassadevirksomhet, som er offentlig virksomhet, noe som med rette legges til grunn i Rt. 2004 s. 402. LB-201650175 burde i stedet vært løst på grunnlag av statsimmunitet, siden det var snakk om krav mot en stat. Da ville faktisk lagmannsrettens drøftelse av om den konkrete transaksjonen var «privatrettslig» vært riktig utgangspunkt. Her ble altså vurderingstemaet som gjelder for statsimmunitet anvendt $\mathrm{i}$ en sak om diplomatisk immunitet.

Det motsatte, altså at vurderingstemaet for diplomatisk immunitet ble anvendt i en sak om statsimmunitet, skjedde i TOBYF-2012-81795. Retten drøftet statsimmunitet og mente at en ambassades virksomhet ikke «kan drives av private». Dette ville altså vært riktig i en drøftelse av diplomatisk immunitet, men det er feil utgangspunkt for en sak om statsimmunitet. Namsfogdens foregående avgjørelse i saken kom nærmere en riktig fremgangsmåte, ved å legge til grunn at unntaket for næringsvirksomhet i VCDR ikke kunne omfatte «leieforhold som angår fremmed stats ambassade i mottakerstaten». Det er riktig. Det ville imidlertid vært tilstrekkelig å slå at fast at VCDR artikkel 22, som verner ambassadeeiendom mot tvangsfullbyrdelse, ikke inneholder noe unntak for kommersiell virksomhet, jf. kapittel 3.1.

\subsection{Unntak for fast eiendom}

Et annet unntak fra diplomatiske tjennestemenns immunitet mot søksmål gjelder saker om fast eiendom i mottakerstaten som ikke brukes av ambassaden. Dette følger av VCDR artikkel 31(1)(a).

LB-2016-50175 anvendte denne regelen i en sak der den ikke var anvendelig. Pakistan var saksøkt på grunnlag av manglende betaling for leie av ambassadebygningen. Lagmannsretten tok «som utgangspunkt at den pakistanske ambassaden kan påberope seg immunitet mot søksmål ved norsk domstol, jf. særlig artikkel $31 \mathrm{nr}$. 1 bokstav a i Wienkonvensjonen». Artikkel 31 nr. 1 gir ikke staten immunitet. Den gir derimot immunitet for diplomater. Det var ingen diplomat som var saksøkt i LB-2016-50175. Artikkel $31 \mathrm{nr} .1$ bokstav a gjør et unntak fra denne personlige immuniteten for diplomater i saker som gjelder fast eiendom, med et unntak fra unntaket i saker den aktuelle eiendommen brukes av ambassaden snarere enn diplomaten personlig. Bestemmelsen var ikke relevant overhodet $i$ en sak mot den pakistanske staten. Derimot ville Pakistan som utgangspunkt hatt statsimmunitet, noe lagmannsretten ikke nevner. Lagmannsretten anvendte altså en bestemmelse om diplomatisk immunitet, som ikke var relevant, i en sak der den skulle anvendt statsimmunitet.

Rt. 2004 s. 402 siterer 2. utgave av Ruud og Ulfsteins Innføring $i$ folkerett, som sier at en stat har immunitet mot «en tvist om eiendommen hvor ambassadebygningen er oppført. Dette følger direkte av reglene om diplomatisk immunitet». ${ }^{62}$ Som nevnt i kapittel 3.1 gir imidlertid diplomatisk immunitet kun vern mot tvangsfullbyrdelse i slike saker. Staten har ikke diplomatisk immunitet mot søksmål i saker om ambassadebygningen. ${ }^{63}$ Høyesterett anvendte

\footnotetext{
${ }^{62}$ Rt. 2004 s. 402 (avsnitt 20).

${ }^{63}$ Carl August Fleischer, Folkerett, 8. utgave, Universitetsforlaget 2005, s. 164.
} 
derfor folkeretten feil på dette punktet. Norske domstoler bør ikke legge denne løsningen til grunn i senere saker. Domstolene bør ta utgangspunktet i statsimmunitet, så lenge det saksøkte er en stat, og anvende statsimmunitetens unntak for fast eiendom.

Når man snakker om VCDR artikkel 22, er det strengt tatt ikke snakk om et «unntak» fra immuniteten for søksmål om fast eiendom. Selve bestemmelsen om immunitet kun nevner tvangsjurisdiksjon. Det er ikke snakk om en generell regel om immunitet som deretter gjør et spesifikt unntak for søksmål.

Det siste av de tre unntakene, i VCDR artikkel 31(1), bokstav b om arverettssaker, har ikke vært oppe i norske domstoler.

\section{AVKALL PÅ IMMUNITET}

Regler om avkall på immunitet finnes i både VCDR og i FN-konvensjonen om statsimmunitet. FN-konvensjonen artikkel 7-9 sier at en stat kan gi avkall på immunitet gjennom uttrykkelig samtykke, deltagelse i prosess eller fremsettelse av motkrav. ${ }^{64}$ VCDR artikkel 32 åpner for at senderstaten gir avkall på diplomatisk immunitet ved en uttrykkelig erklæring eller deltagelse i prosess. VCDR artikkel 22 sier dessuten at «head of mission» ved en ambassade kan samtykke til at mottakerstatens representanter kommer inn på ambassadeområdet. Dette vil være nødvendig for å kunne gjennomføre for eksempel en arrestasjon eller en utkastelse mot noen som befinner seg der.

Avkall på immunitet må som regel gis av staten. Da kan det bli spørsmål om hvilke personer som er legitimert til å gjøre dette på vegne av staten. Det reguleres ikke i VCDR eller FNkonvensjonen. Et avkall på immunitet vil være en ensidig erklæring fra statens side. FNs folkerettskommisjons forsøk på kodifisering av sedvaneretten som gjelder for slike erklæringer sier at det er statsoverhodet, regjeringssjefen og utenriksministeren som kan binde staten uten uttrykkelig fullmakt. ${ }^{65}$ Også i traktatretten kan statsoverhodet, regjeringssjefen og utenriksministeren representere staten utad uten fullmakt, jf. VCLT artikkel 7(2). VCLT artikkel 7(1) åpner dessuten for at en ambassadør kan representere senderstaten overfor mottakerstaten. Dette er en praktisk løsning, som blant annet er lagt til grunn engelsk rett for avkall på immunitet. ${ }^{66}$ Dette har ikke kommet på spissen i norsk rett, men hvis det skulle skje, bør norske domstoler godta avkall gitt av statsoverhode, regjeringssjef, utenriksminister eller den aktuelle ambassadøren. Andre diplomater eller statsansatte kan ikke gi avkall på sin egen eller statens immunitet (med mindre de har fullmakt). Immuniteten tilhører formelt sett staten, ikke den enkelte representanten.

Mange norske husleiekontrakter har en såkalt fravikelsesklausul, som sier at leietaker har vedtatt fravikelse uten søksmål om leien ikke betales, jf. tvangsfullbyrdelsesloven § 132(2)(a). Et interessant spørsmål er om dette kan utgjøre avkall på immunitet $i$ en tvangsprosess om utkastelse. FN-konvensjonen artikkel 7 forutsetter at samtykke kan gis i en «written contract», dersom avkall gjøres «expressly», altså uttrykkelig. VCDR artikkel 22 sier at ambassadøren må gi «consent», altså samtykke, til at representanter for senderstaten skal komme inn på ambassadeområdet. Disse kontraktsklausulene nevner som regel ikke

\footnotetext{
${ }^{64}$ Tilsvarende regler finnes i ECSI artikkel 1-2.

${ }^{65}$ FNs folkerettskommisjon, Guiding Principles applicable to unilateral declarations of States capable of creating legal obligations, with commentaries thereto, 2006, prinsipp 4.

66 The Diplomatic Privileges Act 1964, Section 2(3).
} 
immunitet. Det tilsier at vilkåret «expressly» ikke vil være oppfylt. Slike klausuler er myntet på anvendelsen av den norske tvangsfullbyrdelsesloven, og brukes i alle former for husleieavtaler, ikke bare de som gjelder ambassadelokaler. Derfor bør konklusjonen være at en slik klausul ikke utgjør avkall på immunitet på utkastelsesstadiet. Det er fullt mulig å gi avkall på immunitet i en skriftlig kontrakt, men bør partene ta inn et eget punkt om dette. I saken som ble anket til byfogden i TOBYF-2012-81795, fant namsmannen det «klart» at dette måtte være riktig konklusjon.

HTU-2013-643 la derimot til grunn at en klausul basert på tvangsfullbyrdelsesloven $\S 13$ 2(2)(a) innebar avkall på immunitet allerede i en rettssak om manglende leiebetaling, som ikke engang hadde kommet til tvangsfullbyrdelsesstadiet. Denne løsningen bør ikke legges til grunn i senere saker.

At statsimmunitet går tapt ved fremsettelse av motkrav, sies uttrykkelig i FN-konvensjonen artikkel 9(3). ${ }^{67}$ VCDR artikkel 32(3) sier kun at dersom en diplomat starter en rettsprosess, har vedkomne ikke immunitet mot motpartens motkrav. Det motsatte tilfellet, at noen som har immunitet fremsetter motkrav, er ikke nevnt som et grunnlag for å miste diplomatisk immunitet. Dette må forstås slik at det ikke gjelder noen generell regel tilsvarende FNkonvensjonen artikkel 9(3) for diplomatisk immunitet. ${ }^{68}$

I LB-2016-50175 la imidlertid retten til grunn at «prinsippet i artikkel 9 nr. 3 i FNkonvensjonen [...] må anses som et utslag av et generelt folkerettslig prinsipp». I den saken burde retten heller tatt utgangspunkt i statsimmunitet, og da ville det ikke vært nødvendig å vurdere om prinsippet i artikkel 9 også gjelder for diplomatisk immunitet. Saken kunne for så vidt også vært løst ved henvisning til regelen om at immunitet for søksmål ikke gjelder for visse saker om fast eiendom (jf. kapittel 2.4).

\section{FOLKERETTENS PLASS I NORSK RETT}

\subsection{Sektormonisme i norsk sivilprosess}

Immunitetsreglene følger av folkeretten. I utgangspunktet skal norske domstoler anvende norsk rett. At norsk rett har et dualistisk forhold til folkeretten, ble endelig slått fast i Rt. 1997 s. 580, der førstvoterende skrev at ved «... en klar motstrid mellom folkerettslige bestemmelser og norsk rett, vil imidlertid utgangspunktet måtte være at den interne rett går foran». ${ }^{69}$ I sivilprosessen finner man imidlertid bestemmelser om sektormonisme i henholdsvis tvisteloven $\S 1-2$ og tvangsfullbyrdelsesloven $\S 1-4$. Slike bestemmelser er et praktisk viktig unntak fra utgangspunktet om dualisme. ${ }^{70}$ Ifølge forarbeidene til tvisteloven er et av hovedformålene med $\S 1-2$ nettopp å sikre at norske domstoler anvender folkerettslige immunitetsregler. ${ }^{71}$

\footnotetext{
${ }^{67}$ Det samme følger av ECSI artikkel 1(3).

${ }^{68}$ Eileen Denza, Diplomatic Law: Commentary on the Vienna Convention on Diplomatic Relations, 4. utgave,

Oxford University Press 2016 tar ikke opp spørsmålet.

${ }^{69}$ Rt. 1997 s. 580 (s. 593).

${ }^{70}$ Carl August Fleischer, Folkerett, 8. utgave, Universitetsforlaget 2005, s. 362.

${ }^{71}$ NOU 2001:32 bind A s. 181.
} 
Ifølge tvisteloven $\S 1-2$ og tvangsfullbyrdelsesloven $\S 1-4$ gjelder lovene «med de begrensninger som er anerkjent i folkeretten eller følger av overenskomst med fremmed stat». Dette er en knapp ordlyd, som langt fra løser alle spørsmål om forholdet til folkeretten. ${ }^{72}$

Bestemmelser om sektormonisme kom inn i tvangsfullbyrdelsesloven (og straffeprosessloven) i $1962,{ }^{73}$ og i den gamle tvistemålsloven i 1987 , da $§ 36$ a ble vedtatt. ${ }^{74}$ I Rt. 1938 s. 584 kom Høyesterett til at et krav om midlertidig forføyning mot et skip reelt sett var rettet mot Spanias regjering. Da var «almindelig anerkjente folkerettsregler [...] til hinder for at» kravet «kan fremmes ved en norsk domstol». ${ }^{75}$ Dette var en riktig anvendelse av folkeretten. På dette tidspunktet var det imidlertid ikke noen bestemmelse om sektormonisme i den daværende tvistemålsloven. Førstvoterende mente likevel at «norsk rett må forutsettes å falle sammen med» folkerettens regler. ${ }^{76}$ Det samme ble lagt til grunn i Rt. 1948 s. 706 og Rt. 1949 s. 149. Disse avgjørelsene viser at norske domstoler har vært villige til å anvende immunitetsregler også før vedtakelsen av prosessrettens bestemmelser om sektormonisme. Norsk rett har fortsatt et presumsjonsprinsipp, som sier at «norsk lov så vidt mulig skal tolkes i samsvar med våre folkerettslige forpliktelser», ${ }^{77}$ men dette gjelder kun innenfor «det som med rimelighet kan anses som tolkning av bestemmelsen». ${ }^{78} \mathrm{I}$ dag må en vurdering av immunitet i sivilprosessen bygge på bestemmelsene om sektormonisme.

I tillegg til sektormonismebestemmelser, finnes det en lov om immunitet og privilegier for internasjonale organisasjoner m.v. av 19. juni $1947 .{ }^{79}$ Der viser $\S 1(1)$ til «overenskomst som tiltres av Norge», og sier at disse skal anvendes «uten hinder av norsk lov». I sivilprosessen gir ikke dette noe mer enn det som nå følger av bestemmelsene om sektormonisme. I § 1(3) får imidlertid Kongen adgang til å «uten hinder av norsk lov og uavhengig av mellomfolkelig overenskomst innrømme immunitet og privilegier» til en organisasjon. Dette går utover de generelle bestemmelsene om sektormonisme, ettersom de sistnevnte kun er aktuelle når det foreligger en folkerettslig forpliktelse for Norge.

\subsection{Immunitet som en absolutt prosessforutsetning}

Et annet spørsmål er hvordan immunitet skal klassifiseres i norsk sivilprosess. Der gjelder et skille mellom absolutte og relative prosessforutsetninger. Absolutte prosessforutsetninger skal lede til avvisning uansett om de påberopes, mens relative prosessforutsetninger må påberopes for at retten skal ta stilling til dem. ${ }^{80}$ Det praktiske spørsmålet blir altså om domstolen har et selvstendig ansvar for å avvise en sak der det foreligger immunitet, eller om domstolen kun skal gå inn på dette spørsmålet dersom partene tar det opp.

Ifølge tvisteloven $\S 1-2$ og tvangsfullbyrdelsesloven $\S 1-4$, skal folkeretten gå foran lovenes bestemmelser. Utgangspunktet må derfor tas i hva folkeretten krever. FN-konvensjonen

\footnotetext{
72 NOU 2001:32 bind A s. 181.

${ }^{73}$ Om lov om tillegg til rettergangslovgivningen når det gjelder folkerettslig inmunitet, Lov av 13. april 1962.

${ }^{74}$ Tore Schei mfl., Tvisteloven Kommentarutgave, bind I., 2. utgave, Universitetsforlaget 2013, § 1-2. For tvangsfullbyrdelsesloven ble vedtatt, gjaldt Lov om enkelte bestemmelser om fremmede statsskib m.v. av 17. mars 1939, som blant annet vises til Rt. 1949 s. 881.

${ }^{75}$ Rt. 1938 s. 584 (s. 585).

${ }^{76}$ Rt. 1938 s. 584 (s. 585).

${ }^{77}$ Rt. 2000 s. 1811 (s. 1826).

${ }^{78}$ Rt. 2000 s. 1811 (s. 1831).

${ }^{79}$ Loven vises blant annet til i TSTAV-2013-87525, der en arbeidstaker ikke fikk adgang til norske domstoler på grunn av en avtale med NATO.

${ }^{80}$ Jo Hov, Rettergang $i$ sivile saker, 3. utgave, Papinian 2017, s. 58 legger til at «de relative prosessforutsetningene hører til en utdøende rase».
} 
artikkel 6(1) sier at nasjonale domstoler skal «determine on their own initiative that the immunity of that other State [...] is respected». ${ }^{81}$ Artikkel 8(4) slår fast at fravær i en sak fra en stats side ikke skal tolkes som samtykke til at domstolen behandler saken. Artikkel 23(1) forbyr at det avsies fraværsdom mot en stat uten at domstolen på egenhånd har tatt stilling til immunitetsspørsmålet. Gjeldende folkerett rett er derfor at nasjonale domstoler må anvende reglene om statsimmunitet selv om en saksøkt stat ikke har påberopt seg immunitet. ${ }^{82}$ Dette er lovfestet i ulike rettssystemer, ${ }^{83}$ og følger av rettspraksis $\mathrm{i}$ andre rettssystemer. ${ }^{84}$

Fraværsdom kan ikke avsies før immunitetsspørsmålet er avklart. ${ }^{85}$ Dete må også legges til grunn i norsk rett.

Når det gjelder diplomatisk immunitet, sier ikke VCDR uttrykkelig at nasjonale domstoler skal ta stilling til immunitetsspørsmål på egenhånd. VCDR artikkel 31 sier imidlertid at diplomater «shall [...] enjoy immunity». Denne ordlyden tilsier at immunitet ikke behøver å påberopes. Den motsatte konklusjonen ville vært plausibel dersom det for eksempel hadde stått at diplomaten «may invoke immunity». VCDR artikkel 32 sier at et avkall på immunitet må være «express»», altså uttrykkelig. Da bør ikke manglende påberopelse av immunitet anses som en form for implisitt avkall på immunitet. Norske domstoler skal derfor også ta opp spørsmål om diplomatisk immunitet der det er grunn til det, uavhengig av om dette påberopes.

At domstolene må undersøke immunitetsspørsmål på eget initiativ, er i tråd med tvistelovens system. Tvistelovens forarbeider sier at «utenlandske stater vil ha partsevne for norske domstoler» etter tvisteloven $\S 2-1(\mathrm{~b})$, men at «immunitetsregler [vil] kunne være til hinder for søksmål». ${ }^{86}$ Immunitet har altså mye til felles med manglende partsevne, ved at det det er snakk om et forhold ved den saksøkte som gjør at vedkomne ikke kan saksøkes. Manglende partsevne er en absolutt prosessforutsetning. ${ }^{87} \mathrm{Da}$ er det naturlig at det samme er tilfellet for immunitet.

Én forskjell mellom immunitet og manglende partsevne, som også nevnes i forarbeidene, er at manglende partsevne betyr at man verken kan saksøke eller saksøkes, mens immunitet kun innebærer at man ikke kan saksøkes. ${ }^{88}$ En annen forskjell er at en stat som saksøkes kan gi samtykke til å gi avkall på immunitet, jf. kapittel 4 ovenfor, mens de som ellers mangler partsevne normalt ikke kan samtykke til å gi seg selv partsevne. Det er likevel ikke noe ved disse forskjellene som tilsier at det er grunn til å plassere partsevne og immunitet på ulike sider av skillet mellom absolutte og relative prosessforutsetninger.

Immunitet skal derfor behandles som en absolutt prosessforutsetning i norsk rett. Domstolen må vurdere om det foreligger immunitet, selv om det ikke påberopes. Bevisbyrden for at en

\footnotetext{
${ }^{81}$ Samme regel finnes i ECSI artikkel 6(1).

${ }^{82}$ Xiaodong Yang, State Immunity in International Law, Cambridge University Press 2012, s. 37.

${ }^{83}$ Xiaodong Yang, State Immunity in International Law, Cambridge University Press 2012, s. 39, jf. f. eks. Storbritannias State Immunity Act 1978, Section 1(2).

${ }^{84}$ Xiaodong Yang, State Immunity in International Law, Cambridge University Press 2012, s. 40; for eksempel Aquamar v. Del Monte, US 179 F.3d 1279, 1294 (11th Cir. 1999) fra USA.

${ }^{85}$ Xiaodong Yang, State Immunity in International Law, Cambridge University Press 2012, s. 39-40.

${ }^{86}$ NOU 2001:32 bind B s. 658.

${ }^{87}$ NOU 2001:32 bind B s. 658, og for eksempel Jo Hov, Rettergang i sivile saker, 3. utgave, Papinian 2017, s. 60.

${ }^{88}$ NOU 2001:32 bind B s. 655 .
} 
stat ikke er beskyttet av immunitet, ligger hos saksøkeren, selv når staten ikke er representert i rettssaken. ${ }^{89}$

Underrettspraksis har imidlertid kommet til stikk motsatte konklusjoner om hvorvidt immunitet er en absolutt eller relativ prosessforutsetning. LB-2017-196185 antok at immunitet var en absolutt prosessforutsetning, mens LB-2010-107130 gikk ut fra at det var snakk om en relativ prosessforutsetning som måtte påberopes av partene før retten ville behandle den. Domstolene bør følge LB-2017-196185 i fremtidige saker.

En domstol som mottar en stevning mot noen som har krav på immunitet, skal avvise saken ved kjennelse, jf. tvisteloven § 19-1(2)(1)(a). Dette ble også utfallet i saker som Rt. 2004. s. 402 og NAD-1981-634. Reelle hensyn tilsier at immunitetsspørsmålet bør undergis kontradiksjon og ankemulighet, og det sikres ved at det avsies en formell kjennelse om avvisning. I praksis bør nok uansett en part som nyter immunitet tilrådes å påberope seg dette, siden sakene som er vist til i denne artikkelen viser at dommere ikke nødvendigvis kjenner reglenes innhold eller er klar over at de skal behandles som en absolutt prosessforutsetning.

\subsection{Virkningen av feil}

Det kan bli nødvendig å vurdere hva som skjer dersom domstolene anvender immunitetsreglene feil, og for eksempel avsier dom i en sak som skulle vært avvist på grunnlag av immunitet. En dom blir i utgangspunktet rettskraftig når «den ikke lenger kan angripes med ordinære rettsmidler», som anke og oppfriskning, jf. tvisteloven § 19-14(1). Dette utgangspunktet gjelder også når retten har oversett at en absolutt prosessforutsetning ikke er oppfylt. En annen sak er at immunitetsreglene vil gjøre det vanskelig å fullbyrde en eventuell dom, selv om den skulle være rettskraftig.

Tvisteloven $\S 16-12(1)$ åpner for at det begjæres oppfriskning mot en avvisningskjennelse ved fravær eller en fraværsdom som «er avsagt med urette». Dersom en slik avgjørelse er avsagt til tross for at en part hadde immunitet, vil avgjørelsen være «avsagt ved urette» og oppfriskning kan gis. Dette ble også løsningen i LB-2017-196185, der lagmannsretten ga oppfriskning fordi den opprinnelige avgjørelsen ikke drøftet immunitet (i tillegg til at saken var fremsatt mot feil saksøkt og søksmålet sannsynligvis ikke var riktig forkynt).

Etter $§ 16-13$ gjelder det en frist på én måned for å be om oppfriskning fra forkynnelse av avgjørelsen eller fra forsømmelsen fant sted. Dersom denne fristen oversittes, gjelder de samme reglene om oppfriskning vedrørende fristoversittelser. Når fristen er utløpt, kan man ikke begjære oppfriskning, selv om den opprinnelige avgjørelsen var truffet i strid med folkeretten, til tross for folkeretten skal gå foran tvisteloven. Dette er i tråd med tvistelovens forarbeider, som forutsetter at $\S 1-2$ kun medfører at folkeretten går foran tvisteloven ved motstrid, og at folkeretten ikke skal kunne supplere tvisteloven i spørsmål som tvisteloven ikke regulerer. ${ }^{90}$ Folkeretten må gis gjennomslag innenfor sivilprosessens nasjonale prosessuelle rammeverk.

\footnotetext{
${ }^{89}$ Xiaodong Yang, State Immunity in International Law, Cambridge University Press 2012, s. 41.

${ }^{90}$ Ot.prp. nr. 51 (2004-2005) s. 363.
} 
Dersom den uriktige avgjørelsen ikke er en fraværsdom eller avvisningskjennelse, kan ikke oppfriskning begjæres. Da er man i første omgang henstilt til å anke. Ankedomstolen må på selvstendig grunnlag ta stilling til om absolutte prosessforutsetninger er oppfylt. ${ }^{91}$

Dersom anke ikke fører frem, kan man eventuelt begjære gjenåpning. Vilkårene for gjenåpning følger av tvisteloven $\S 31-3 \mathrm{og} \S 31-4$, som gjelder feil ved henholdsvis «rettergangen» og «avgjørelsen». § 31-3(1)(a)-(c) gjelder forhold ved dommere eller vitner, mens (e) gjelder når «parten ikke møtte». § 31-4(a) gjelder «faktiske forhold», ikke rettsregler (som immunitetsreglene). § 31-4(d) og § 31-4(b) gjelder kun når man har en «internasjonal klagesak» eller «avgjørelse av en internasjonal domstol eller en uttalelse fra FNs menneskerettskomité». Ingen av vilkårene $\S 31-3$ og $\S 31-4$ gir grunnlag for å gjenåpne en dom fordi den er avsagt i strid med immunitetsregler. Dermed kan en dom avsagt i strid med folkerettslige regler bli rettskraftig uten at mulighet for gjenåpning, til tross for reglene om sektormonisme.

Det er for så vidt mulig å tolke tvisteloven $\S 1-2$ og tvangsfullbyrdelsesloven $\S 1-4$ slik at en avgjørelse avsagt i strid med folkerettslige regler er en nullitet. Det er imidlertid vanskelig å se at lovens system åpner for en slik løsning. En feilaktig dom må angripes med de prosedyrer loven selv tilbyr, også der dommen er feilaktig fordi den er i strid med folkeretten. Dette er i tråd med forarbeidenes forutsetning virkningen av $\S 1-2$, som nevnt ovenfor. Det betyr at den beste fremgangsmåten for noen som har immunitet er å påberope immunitet, men det nest beste er å ikke møte og få en fraværsdom. Det dårligste alternativet er å møte opp uten å påberope immunitet.

\section{JURIDISK METODE I IMMUNITETSSAKER}

De foregående kapitlene gir grunnlag for å si noe mer generelt om juridisk metode i saker om immunitet.

Når man analyserer norsk rett, kan en norsk dom være en avgjørende rettskilde i seg selv. Dette er annerledes når man anvender immunitetsreglene. De er folkerett, og folkeretten må tolkes ved hjelp av folkerettens kilder. ${ }^{92}$ Nasjonal rettspraksis fra én stat, som for eksempel Norge, er ikke en tungtveiende rettskilde i folkeretten. ${ }^{93}$ Flere av konklusjonene i denne artikkelen utfordrer derfor den tradisjonelle norske metodelæren. For eksempel er det uvanlig å anbefale at norske jurister ikke følger en høyesterettsdom, og heller følger en avgjørelse fra lagmannsretten, slik denne artikkelen gjør. Den norske prejudikatslæren er i det hele tatt til liten hjelp i saker om immunitet. Dommere kan ikke være sikre på at tidligere avgjørelser har tolket folkeretten riktig, og folkeretten kan uansett ha endret seg siden den forrige avgjørelsen ble avsagt.

Rollen EMD har påtatt seg på immunitetsfeltet, gjør situasjonen enda mer komplisert for nasjonale domstoler. EMDs oppgave er i utgangspunktet å tolke EMK, og norske domstoler tillegger EMDs tolkninger stor vekt ved tolkningen av EMK. ${ }^{94}$ EMK handler ikke om

\footnotetext{
${ }^{91}$ NOU 2001:32 bind B s. 884.

${ }^{92}$ Finn Arnesen og Are Stenvik, Internasjonalisering og juridisk metode, 2. utgave, Universitetsforlaget 2015, s. 18.

${ }^{93}$ Alain Pellet, «Article 60», i Andreas Zimmermann mfl. (red.), The Statute of the International Court of Justice: A Commentary, 2. Utgave, Oxford University Press 2019, s. 731, s. 862.

${ }^{94}$ For eksempel Rt. 2005 s. 833 (avsnitt 45).
} 
statsimmunitet. EMD har likevel tolket FN-konvensjonen om statsimmunitet, fordi EMDs syn er at rettighetene i EMK setter grenser for reglene om statsimmunitet. Dersom norske domstoler tolker FN-konvensjonen videre enn hva EMD gjør, kan EMD dømme Norge for brudd på EMK. Norske domstoler er derfor i praksis også nødt til å legge stor vekt på EMDs tolkning av FN-konvensjonen.

Tvisteloven $\S 11-3$ krever at retten «av eget tiltak anvende gjeldende rettsregler». Immunitet er dessuten en absolutt prosessforutsetning, som nevnt ovenfor. Det er altså hver enkelt dommers ansvar å anvende folkeretten riktig i saker der det blir nødvendig, også i saker der partene ikke har prosedert på det. I praksis er nok dette et felt der juridisk litteratur blir en viktig informasjonskilde.

\section{KONKLUSJON}

Én konklusjon som kan trekkes på grunnlag av denne artikkelen, er at immunitetsspørsmål har vært forholdsvis praktisk viktige i norsk sivilprosess. De har vært oppe for norske domstoler en rekke ganger, og de vil også dukke opp i fremtidige saker. Samtidig har de ikke dukket opp hyppig nok til at domstolene har klart å skape en konsistent praksis.

Artikkelen har dessuten vist at selv om utgangspunktet for forholdet mellom norsk rett og folkeretten kan virke enkelt, reiser det mange intrikate spørsmål i praksis. Ordlyden i sektormonismebestemmelsene gir svært begrenset veiledning for løsningen av mange av disse spørsmålene. Særlig er rettstilstanden rundt arbeidsavtaler uklar. Her er den internasjonale rettstilstanden i noen grad fortsatt i støpeskjeen, siden man har en åpent formulert konvensjon som ikke har trådt i kraft. At EMD også har vært involvert, og har stilt sine egne krav, gjør situasjonen enda mer komplisert.

Denne artikkelen viser også at selv om norsk sivilprosess har regler om sektormonisme, der folkeretten skal gå foran norsk rett, går det en grense for folkerettens gjennomslag. De folkerettslige immunitetsreglene kan bare anvendes innenfor prosesslovgivningens nasjonale rammeverk i hver enkelt stat. 